\title{
Active aging: an intervention-research report
}

\author{
Giselle Massi ${ }^{(1)}$ \\ Frances Tockus Wosiacki ${ }^{(1)}$ \\ Ana Cristina Guarinello(1) \\ Adriana Bender Moreira de Lacerda(1) \\ Telma Pelaes de Carvalho(1) \\ Ana Cláudia Wanderbrooke ${ }^{(1)}$ \\ Nanci Garcia Cairo(1) \\ Roxele Ribeiro Lima ${ }^{(1)}$
}

(1) Universidade Tuiuti do Paraná, Curitiba, Paraná, Brasil.

Conflict of interest: Nonexistent

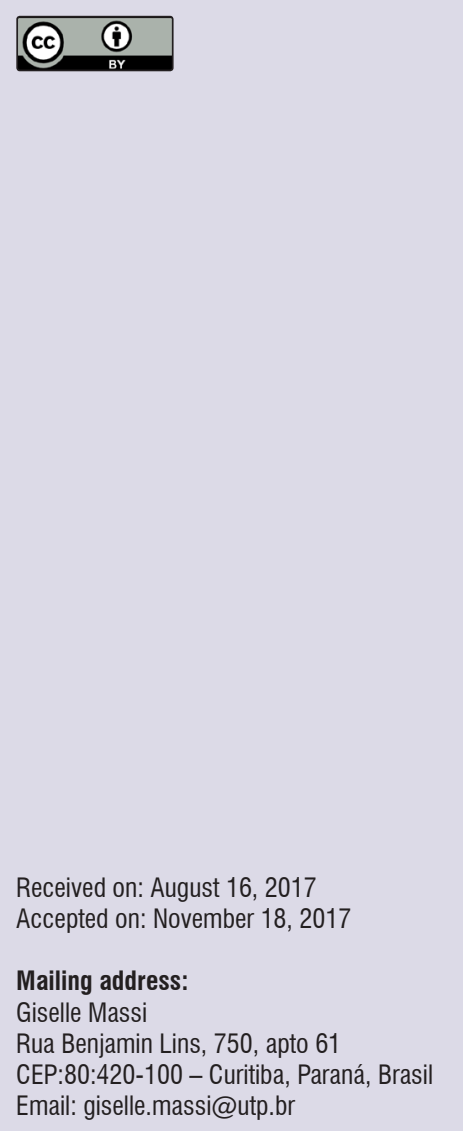

\section{ABSTRACT}

Purpose: this study aimed to analyze significant effects of language activities on elderly people's autonomy and social participation.

Methods: it is an intervention research report, based on a dialogical discourse perspective, developed in two stages. In the first, a speech-language intervention involving written and oral practices about life stories was carried out with six elderly participants. In the second, a semi-structured interview was applied with these participants based on questions that addressed the aims of the study.

Results: the participants were all females, aged between 61 and 90 years old. Their statements indicated that, through dialogical practices, they were able to increase their social participation, autonomy and self-esteem; they were also able to deconstruct stigmatizing social standards imposed to elderly people.

Final Considerations: dialogical practices among the elderly can help promote active aging and overcome negative conceptions about elderly people, as proposed by the World Health Organization and the National Health Care Policy for the Elderly, which confirm that elderly people contribute to social development.

Keywords: Aging; Social Participation; Personal Autonomy; Language 


\section{INTRODUCTION}

Currently, discussions on aging and old age have been highlighted, indicating that Brazilian elderly population have faced discriminating and prejudiced situations, not only in a larger social scope, but also within their own families ${ }^{1}$. Such situations, typical from a marginalizing and oppressive socioeconomic context, unfold that part of the current capital-based society, focused on the production and consumption, considers elder people as unproductive and incapable of contributing to the community that they live in ${ }^{1}$.

Thus, aging confronts the economic capitalist organization ${ }^{2}$, once that organization is focused on the workforce. Elderly exclusion in such a socioeconomic system, is due to the fact that it demands workforce exercised by young people, that is, by people who are considered healthy, vigorous, physically fit to produce and consume goods.

Following that reasoning, once retired from the labor market, and probably having their purchasing power reduced, older people are not recognized as productive anymore. Among the factors justifying aged people's removal from social and work settings are their physical changes. They occur naturally along the time, causing visual and hearing impairments, vocal changes, added by esthetic alterations, among others, considered demeaning in the Western culture, which takes productive, consuming, young people as the model ${ }^{3}$.

In this context, old age is viewed negatively, related to the biomedical knowledge, grounded in a biological and mechanistic view of the human being, assuming a curative approach for diseases ${ }^{2}$. That perspective, which assumes a simplistic view of aging as a succession of organic losses, contributes to the dehumanization of old age, and causes a contradicting pursue for the eternal youth ${ }^{3}$. Such a simplification, typical from an adult-centered society, brings about discriminating stereotypes around the aging process, and prevents the elderly from a significant social interaction, which would enable them to continue integrated in their families and communities. Moreover, it is necessary to point out that such a hegemonic view of old age contradicts international ${ }^{4}$ and national ${ }^{5}$ recommendations related to the health promotion of older people.

In order to rethink old age from another view, the World Health Organization (WHO, 2005) ${ }^{4}$ has been pondering over the process of health optimization of the older subjects. According to the $\mathrm{WHO}$, it is necessary to recognize that those subjects can and must steadily participate in the decisions on the structural aspects of the community that they live in, such as economic, cultural, spiritual, civil aspects, among others ${ }^{4}$. Thus, active aging is proposed, elucidating that the expression does not refer to physical strength, but to the elderly people's social participation, pointing to a new conception on old age. In that proposal, older people are viewed beyond merely organic aspects, and they may be qualified as contributors to and beneficiaries from the social development.

Pursuing that perspective, the National Health Care Policy for the Elderly, grounded in the recognition of elderly people's rights and in the tenets of independence, participation, autonomy, dignity, care and selffulfillment, set up by the United Nations Organization (UNO), establishes the promotion of active and healthy aging as one of its guidelines, keeping in mind older subjects' social interaction ${ }^{5}$.

In that sense, it is worth pointing the role of language in the promotion of active aging, because it is through the language, conceived as a dialogical activity, that elderly people participate in the society that they live in ${ }^{6}$. It is by means of the dialogue that people, in different stages of life, influence each other, participating and changing the community that they live in ${ }^{7}$. Therefore, the development of effective oral and written practices, in the aging process, must take on their significant role, to the extent that they expand older people's power of decision and social integration.

Thus, focusing on active aging, and understanding that dialogical practices are necessary for old age to be experienced in a healthy way, the current study objectifies to analyze the effects that significant language activities may have on the autonomy and social participation of the elderly.

\section{METHODS}

The current study is an intervention research, grounded in a dialogical perspective of the discourse, in terms of Bakhtin's philosophy of the language ${ }^{8}$. It is a study approved by the Committee of Higher Education at the Tuiuti University, protocol number 102/2008, which associates knowledge production and actions towards health promotion. Thus, considering the criteria of the Resolution $466 / 2012$ by the National Health Board, all participants signed the Free Informed Consent Form.

Intervention-research assumes that a researcher investigates with the subjects, not about them, taking 
the relationship to each other as the primary assumption of the study 9 . Thus, that type of research, grounded in the principle of otherness ${ }^{10}$, entails the understanding that the relationship between researcher and research participants is a basic condition for its development, assuming that all knowledge is historically produced and socially shared ${ }^{11}$.

Six (6) older people participated in the current study, recognized by their fictitious names, who integrated an activity of language promotion, elaborated under dialogical activities. It is necessary to elucidate that the elderly looked for that activity due to informative posters placed at the nearest Health Care Unit from the University where the dialogical practices were carried out. In those posters, elderly people over 60 years, interested in telling their life stories, were invited to join the Language Workshop, being informed about the contact for enrolment. In addition to the elderly, young trainees from the Speech-Language Therapy Course of a University located in Southern Brazil, and speechlanguage researchers were involved.

The activities relied on the elaboration of oral and written accounts of life stories, developed in weekly meetings, about 90 minutes each, throughout 2015. In those meetings, the elders chose to discuss subjects which addressed their artistic predispositions. In order to carry out such thematics, during the first semester of 2015 , the group visited a museum and, in some meetings, participated in lectures and talked to several regionally renowned artists, among them: a painter, a photographer, a cartoonist and a sculptor. In addition, they read texts on different genres about current artistic productions.

More specifically, during the first semester, the dialogical activity focused on group text readings, which enabled oral discussions developed by the participants, considering their individual interpretation. Those unique interpretations, grounded in their knowledge and personal experiences, not only intensified the discussions, sometimes controversial, but also allowed the elders to perceive that they could take the authorship of what they had read. They realized that the reading activity could and should establish a close connection with their experienced contents.

In the second semester of the same year, after the reading practices, a text production activity was begun, organized according to their personal experience speeches. Those experiences, involving artistic activities, such as drawings on fabric, creative cooking, paintings, photographs, among others, which were part of the participants' daily lives, were initially shared orally. Each older individual would tell part of his/her life story, while the others would listen and make comments. Subsequently, each one wrote his/her account, and read it to the others, who would ask questions, point to narrative gaps, give suggestions, generating questions on the formal and discursive aspects of the elaborated texts.

The questions addressed by the participants played a significant role in the individual re-elaboration of the texts. Finally, after that re-elaboration, the individual texts were changed into a book chapter. Thus, taking the dialogical perspective as reference for that practice, once the language, a symbolic activity, promotes the continuous reorganization in each subject's history, the participants allowed themselves to write their own personal accounts, publishing a book named "A arte não tem idade" ("Art is ageless").

In November of 2015, when the activity focusing on language promotion ended, the elderly participants answered, orally and individually, a semi-structured interview. The average time of each interview was 40 minutes. Each interview was recorded by means of an LG-E612f mobile phone, and then fully transcribed. That interview, understood as an enunciation device, able to encourage the subjects to produce texts, in addition to questions on the elderly subjects' demographic profile, comprised questions in order to understand the effects that effective activities with the language had on the participants' autonomy and social interaction.

The unit of analysis in the study was the discursive activity itself, developed during the interview. That activity corresponds to an interactive, semiotically mediated situation, according to the dialogical perspective underpinning the study' ${ }^{9}$. Therefore, the questions, which guided the interviews, are listed in the clarification of the results, before the answers elaborated by the participants. Thus, it is possible to consider it a discursive context, where participants' speeches were produced, as follows.

\section{RESULTS}

The results are organized in three axes. The first axis portrays the demographic profile of the participants. The second and third axes evidence the discursive productions related to the dialogical activities on autonomy and social participation of the studied subjects. 


\section{First Axis: Profile of the research participants}

The first axis features the data of people who participated in the study, describing aspects related to gender, age, marital status, monthly income, schooling, as shown subsequently.

Bianca: She is a sixty-eight-year-old woman, divorced, retired, with a monthly income of five minimum wages. She lives alone, gets along with her mother, siblings, children, grandchildren and friends. She has superior level of schooling.

Cora: She is an eighty-three-year-old woman, widow, retired with a monthly income of three minimum wages. She lives alone, gets along with neighbors and group peers that she attends. She has superior level of schooling.

Carina: She is a sixty-four-year-old woman, divorced, retired, with a monthly income of one minimum wage, lives alone, gets along with two children and neighbors. She has middle-school level of education (8 years).

Erica: She is a sixty-one -year-old woman, married, retired, with a monthly income of two minimum wages. She works to complement her income, lives with her husband and a son, gets along with grandchildren and siblings. She has high-school level of education.

Gislene: She is a sixty-seven-year-old woman, single, retired, with a monthly income of five minimum wages. She lives alone, gets along with friends and neighbors. She has superior level of schooling.

Yolanda: She is a ninety-year-old woman, widow, retired, with a monthly income of one minimum wage. She lives with her children and gets along with friends, neighbors, and peers of groups that she attends. She has incomplete middle-school level of education.

\section{Second axis: Effects of dialogical activities over elderly people's autonomy}

In order to understand the effects of the dialogical practices over the autonomy of older people, each one was asked whether the activity of language promotion had influenced or not their autonomy. The answers to that question are shown below.
Bianca: Yes, when I started participating in the group, my self-esteem improved, I got more self-confident, when I'm willing to do something, I do it for me, not for the others.

Cora: Yes, it helped because we work on our disability, I realized that I was more dependent than I really am with my family caring, I said it was enough and became more autonomous than I was.

Carina: I think so, since we talked about, l've been able to explain people about my impairments better, it's my right, for example, to take a seat on the bus, I'm not afraid of asking for a seat, I express myself differently.

Erica: What's been worked here has helped me consider my possibilities, everything I can do, we don't fall behind just because time passed by for us.

Gislene: Yes, here we're invited to face ourselves, the ideal in this activity is that you're not supposed to shut up, then I feel that the group has made me consider my possibilities.

Yolanda: Yes, I made a commitment to be here on the assigned day and time. Then, by keeping that commitment, I develop my autonomy.

By following the elderly women's discursive productions, it is possible to state that the dialogic activities which they took part, influenced the autonomy of all participants.

Among the effects of those activities, they point out: more confidence to make decisions; the need to step away from their families' excessive care e get more independent; valuing their own rights and the possibility to express them fearlessly; the understanding that it is possible to plan and carry out actions in old age, therefore, aging should not be seen as negative; recognition that old age is the moment of life when it is possible to be committed to your own welfare.

\section{Third axis: Effects of the dialogical activities in older people's social participation}

In order to analyze aspects related to their social participation, the interviewer asked the older women two questions. The first one, she requested them to answer whether, in their opinion, the dialogical activities, developed along a year, had provoked or not changes in their social relationships. And, in case all of 
them answered it affirmatively, they were requested to explain such changes.

Bianca: I see the problems in a different way, we deconstructed the standards imposed by society. Each one must be accepted the way he/she is, because society imposes standards, and I learned here that we must stand up for our opinions, and what we like.

Cora: There was a big change, my self-esteem was down on the floor, and I raised it to the clouds, to the top.

Carina: I let myself go more. I could realize that it's fine when I don't know about a thing.

Erica: I felt inspired about talking after I started to participate [in this activity]. I don't know if it's because I feel accepted.

Gislene: Here [...] we feel at ease, then I feel I'm freer to state my point.

Yolanda: I've never imagined to be so free to tell my story, I felt important.

The enunciations produced by the elderly women unfold that, in their opinion, their involvement in dialogical activities may expand their social participation. To the participants, such activities generate possibilities so that they could: state their own point of view; put down imposed social standards; recognize the value of their own experiences; have inspiration and freedom to speak to the other. Moreover, for an elderly woman, the participation in dialogical practices contributed to raise their self-esteem.

Proceeding the interview, in order to deepen the understanding on the influence of dialogical activities in the expansion of the elders' social participation, the interviewer elaborated the following question: "In your opinion, the activity carried out this year, with the language, can help older people to keep on being participants in the family and in the group that they live in?" Answering the interviewer, the elderly women elaborated the enunciations as follows:

Bianca: The fact that this activity allows us to discuss varied subjects broadens our way to view life, and we take it home. We feel like sharing with our closest people what's discussed here.

Cora: Yes, it can a lot, because it's like college, many people think we are attending a course. And, actually, we are, but it's different... it's a workshop.
We pass on a lot of what we've learned here to the young, and people can better understand the elders.

Carina: Yes, because we told part of our story here. And, then, I understood that everyone has difficulties, and this helps us not to give up and move on.

Erica: We realize that there are people who hold back even more, they end up not having the chance to speak by themselves. I come here because I like it, but this space is an opportunity for many people who don't have other spaces to be heard.

Gislene: I think the most important is that it encourages people to leave home and exercise, and think. That's very important, when you look for things outside your place, it helps get out of the depression.

Yolanda: It seems to me that we're teaching here, even if I didn't attend university, I have life experience. That's praised here, it's a chance to talk about our knowledge, it's very good.

The enunciations elaborated by the elderly participants indicate that by working with and on the language, in a dialogical perspective, enabled them to expand the understanding of facts from their own lives, positively influencing the relation that they establish with people that they interact. Moreover, it brought about relationships between different generations; it valued the experience accumulated through a lifetime; it promoted greater acceptance of their own difficulties and the others'; it encouraged social participation.

\section{DISCUSSION}

Regarding the first axis, related to the social profile of the research subjects, it was evidenced that all participants were women. That female prevalence is also shown in the statistical profile of the Brazilian Institute of Geography and Statistics ${ }^{12}$, which evidences that women are majority among Brazilian aging population. Similarly, another study carried out in a Southern Brazilian capital city, with over 70 older people, indicates that $90 \%$ of them were females ${ }^{13}$. That prevalence of female participants can be justified by the social role imposed to males in the current cultural context, which outlines the expectation that a man should be strong, manly and invulnerable. Research evidences that, to meet that expectation, Western males usually search less than women for health care services and group activities ${ }^{14}$. 
In relation to the income, it was demonstrated that participants' monthly earnings are directly proportional to their level of schooling. It means that those having Higher Education earn equivalent average salaries to 3 and 5 minimum wages. The participants with middle school level of education earn 1 minimum wage, and the participant with high school level of education has a monthly income of two minimum wages, as she complements her retirement pension. Similar results were evidenced in another study, which shows that elderly people with Higher Education have a monthly income between three and five minimum wages, significantly higher than those who have lower schooling ${ }^{15}$.

The second axis is about the effects of dialogical activities on the participants' autonomy. According to the National Health Care Policy for the Elderly ${ }^{5}$, autonomy pervades all people's actions through their lives, and it must be ensured to the aging population. From that autonomy, each elder person must actively participate in the decisions involving his/her life as well as the community he/she lives in. In the speeches presented in axis 2, the participants mentioned that, after their participation in a group focusing on the development of dialogical activities, they were more self-confident to make decisions; they perceived the need to step away from their family excessive care, and become more independent; they value their own rights and the possibility to express them fearlessly.

In general, the participants' speeches are in conformity with another study which points that group activities may support the elderly, encouraging their search for autonomy and independence ${ }^{16}$. According to that study, such encouragement expands the possibility for the elders to cope with their insecurities, enabling them more resilience to face the difficulties ${ }^{16}$.

The participants' enunciations also unfold that language activities led them to understand that old age should not be seen as something negative. It is the moment of life when it is possible to get committed to your well-being. Thus, from those enunciations, it is possible to state that the dialogical activities carried out with those elderly women enabled them to question the demeaning standards imposed by the Western capitalist society, which disregards active aging.

A study claims that the engagement in social and leisure activities enables the expansion of the psychological well-being and greater social interaction of older people ${ }^{17}$. According to the authors, in group relations, subjects can organize their self-image by answering who they think that they are, they perceive their physical and psychological traits, and their qualities or shortcomings ${ }^{16}$. Thus, it is possible to apprehend that the dialogical relations established during the group meetings can expand the acceptance of aging, favoring well-being and promoting elders' satisfactions and self-esteem.

Regarding the third axis, on the effects of the dialogism in elderly people's social participation, the enunciations produced by the participants evidenced that, in their point of view, the involvement in dialogical activities may expand their social inclusion, positively influencing in the relations established with people from different generations, part of their interaction, according to the evidenced in another study on the role that dialogical activities plays in the intergenerational reciprocity ${ }^{18}$. Moreover, they mentioned that they perceived the importance to put forward their own point of view, as well as the acceptance of their own limitations. Such data are according to another study which claims that meaningful language group practices enable (re)elaborations of their own life story, bringing about greater social participation ${ }^{19}$.

It was possible to apprehend in the participants' speeches that the development of discursive actions led them to value their knowledge and life stories. Thus, they could overcome limiting daily situations, participating, in a broader way, in the community that they live in. In that sense, another study ${ }^{20}$, focused on aspects related to older people's health promotion, discusses the importance of valuing individuals' own knowledge in their process of empowerment.

The participation in activities with and about the language led older people, participants in the study, to report positive changes in their decisions and positioning towards the other, not only in the family scope, but also in a broader social scope. Thus, they were able to claim that the effective use of orality and writing in the aging process expanded their power of decision making as well as their social inclusion. However, due to the unique nature of all dialogically oriented research and the restricted number of participants, it deems to clarify that their speeches and the discussion generated by them cannot be transferred to other populations.

\section{FINAL CONSIDERATIONS}

The results of this research point that the dialogical activities had positive effects on the social participation and autonomy of the elderly participants. Among the effects of those activities in the social participation, 
the older subjects pointed out a greater possibility to value their experiences and put forward their point of view. Regarding their autonomy, they reported more confidence to make decisions, the need to step away from the excessive family care and stand up for their independence, valuing their rights and possibility to express them fearlessly, added by the recognition that it is possible to be committed to their own well-being in old age.

Thus, it should be pointed out the relevance of interventions considering dialogical practices to that population, which may promote active aging, according to what is proposed by the World Health Organization and National Health Care Policy to the Elderly.

\section{REFERENCES}

1. Scortegagna PA, Oliveira RCS. Educação: integração, inserção e reconhecimento social para o idoso. Rev Kair Gerontol. 2010;13(1):53-72.

2. Moraes GVOB. Influência do saber biomédico na percepção da relação saúde/doença/incapacidade em idosos da comunidade [dissertação]. Belo Horizonte (MG): Fundação Oswaldo Cruz; 2012.

3. Oliveira MCR, Fernandes M, Carvalho RR. O papel do idoso na sociedade capitalista contemporânea: uma tentativa de análise. In: V Jornada Internacional de Políticas Públicas. Anais; Agosto de 2011; UFMA. Maranhão. On line. Disponível em http:// www.joinpp.ufma.br/

4. World Health Organization. Envelhecimento ativo: uma política de saúde. Brasília, DF: Organização Pan-Americana de Saúde, 2005.

5. Brasil. Portaria № 2.528, de 19 de outubro de 2006. Aprova a Política Nacional de Saúde da Pessoa Idosa. Brasília, DF: Ministério da Saúde, 2006.

6. Massi G, Berberian AP, Guarinello AC, Lourenço RCC, Tonocchi R. Language and aging: written autobiographical practices with elderly. Rev. CEFAC. 2015;17(6):2065-71.

7. Souza IAL, Massi G, Berberian AP, Guarinello AC, Carnavale $L$. The impact of discursive linguistic activities in promoting the health of elderly people in a long-term care institution. Audiol Commun Res. 2015;20(2):175-81.

8. Bakhtin M. Estética da criação verbal. $3^{a}$ ed. São Paulo: Martins Fontes; 2000.

9. Jobim e Souza S, Albuquerque EDP. A pesquisa em ciências humanas: uma leitura Bakhtiniana. Rev Estudos do Discurso. 2012;7(2):109-22.
10. Amorim M. O pesquisador e o seu outro: Bakhtin nas ciências humanas. São Paulo: Musa Editora, 2004.

11. Barros JPP, Colaço VFR. Drogas na escola: análise das vozes sociais em jogo. Educ e realidade. 2015;40(1):253-73.

12. Instituto Brasileiro de Geografia e Estatística. Mudanças demográficas no Brasil no início do século XXI: subsídios para as projeções da população. Rio de Janeiro: Ministério do Planejamento, Orçamento e Gestão, IBGE, 2015.

13. Souza Filho PP, Massi GA. Letramento de idosos brasileiros acima de 65 anos. Distúrb Comun. 2014;26(2):267-76.

14. Alves RF, Silva RP, Ernesto MV, Barros AGL, Souza FM. Gênero e saúde: o cuidar do homem em debate. Psicol Teor Prat. 2011;13(3):152-66.

15. Souza FPP, Massi GAA, Ribas A. Escolarização e seus efeitos no letramento de idosos acima de 65 anos. Rev. Bras Geriatr Gerontol. 2014;17(3):589-600.

16. Both JE, Leite MT, Hildebrandt LM, Pilati ACL, Stamm B, Jantsch L. Grupos de convivência: uma estratégia de inserção do idoso na sociedade. Rev Contexto Saúde. 2011;10(20):995-8.

17. Macêdo CMV, Andrade RGN. Imagem de si e autoestima: a construção da subjetividade no grupo operativo. Psicol Pesq. 2012;6(1):74-82.

18. Massi G, Santos AR, Berberian AP, Ziesemer NB. Impact of dialogic intergenerational activities on the perception of children, adolescents and elderly people. Rev. CEFAC. 2016;18(2):399-407.

19. Lourenço RCC, Massi G, Lima RR. Language and aging: a search for resignifications of life stories. Rev. CEFAC. 2014;16(2):672-8.

20. Finger D, Gomes AM, Schröder JD, Germani ARM. Promoção da saúde e prevenção de doenças: idosos como protagonistas desta ação. Revista de Enfermagem FW. 2015;11(11):80-7. 